\title{
Identifying target species and seed sources for the restoration of threatened trees in southern Brazil
}

\author{
P. M. Hoffmann, C. T. Blum, S. J. E. Velazco, D. J. C. Gill and M. Borgo
}

\begin{abstract}
Ecological restoration of trees is often constrained by limited knowledge of the biology, propagation and management requirements of individual species. Consequently, restoration initiatives rarely incorporate less well-known species or those that are difficult to source and grow. We describe challenges associated with the restoration of threatened trees in the Araucaria Forest of southern Brazil, and analyse the effectiveness of methods used to define target species, identify seed sources and generate information on the phenology of rare or threatened tree species. A review of secondary data identified 71 rare or threatened taxa as targets for seed collection. We then surveyed $68.7 \mathrm{~km}$ of trails in 26 forest remnants, identifying and mapping 1,027 seedproducing trees of 38 species. Surveys confirmed the scarcity of several tree species (including seven species with an abundance of $<0.04$ individuals per $\mathrm{km}$ ), and nine species showed no signs of fruiting during 3 years of phenological monitoring. These findings, together with limited knowledge and application of optimal seed collection methods, are significant factors impeding the recovery of these species within their natural habitat. Wider application of the results of this case study could support restoration of the Araucaria Forest with seedlings from a wider diversity of species.
\end{abstract}

Keywords Araucaria Forest, Brazil, conservation, phenology, propagation, seed collection, subtropical forest restoration, threatened species

This paper contains supplementary material that can be found online at http://journals.cambridge.org

\section{Introduction}

The restoration of damaged but previously complex ecosystems may be one of the greatest challenges facing tropical forest conservation (Rojas-Briales \& Weise, 2014).

P. M. Hoffmann (Corresponding author), S. J. E. Velazco and M. Borgo Sociedade Chauá, 82130-010, Curitiba, Brazil. E-mail pblhffmnn@gmail.com

C. T. Blum Departamento de Ciências Florestais, Universidade Federal do Paraná, Curitiba, Brazil

D. J. C. GiLl Fauna \& Flora International, Cambridge, UK

Received 16 June 2014. Revision requested 6 August 2014

Accepted 11 November 2014. First published online 11 March 2015.
Targets have been set to restore $15 \%$ of degraded land by 2020 (CBD, 2010) but restoration efforts are often constrained by lack of knowledge of the biology, propagation and management of tree species or by a lack of sufficient seed (Merritt \& Dixon, 2014). A reliable source of highquality seed is critical to the success of restoration projects, directly influencing the germination and survival of seedlings and the genetic diversity of populations (Zahawi \& Holl, 2014).

These challenges are particularly pertinent to the Brazilian Atlantic Rainforest, a biodiversity hotspot (Myers et al., 2000) with $>20$,000 plant species and 1,500 animal species interacting across multiple trophic levels (Mittermeier et al., 1999; Ribeiro et al., 2009). Less than $12 \%$ of the forest remains, in isolated remnants, many of which are highly degraded (Ribeiro et al., 2009). Attempts to restore the biome have evolved from projects focusing on a small number of fast-growing species (most of which failed to establish into self-perpetuating forest; Barbosa et al., 2003) to initiatives adopting a high-diversity planting approach (e.g. planting 80-9o tree species; Rodrigues et al., 2009). For many tree species, however, a lack of information on their reproductive biology prevents their inclusion in restoration projects (Rodrigues et al., 2009).

The Araucaria Forest is one of the most threatened ecosystems in the Atlantic Rainforest biome. In Paraná state, where Araucaria Forest was once the dominant vegetation type, covering $8,295,750$ ha (Maack, 2012), <o.8\% of the original forest remains in advanced successional stages, none of which is considered primary forest (Castella \& Britez, 2004). Such extensive fragmentation means that areas left to regenerate without human assistance never attain the full range of naturally occurring species (Liebsch et al., 2008).

Restoration is the main mechanism available to restore species richness in the Araucaria Forest, but seed collection and tree planting tend to be focused on a narrow range of species. Partly as a result of low seed collection effort, only 56 of the 352 tree species found in Araucaria Forest (Leite \& Klein, 1990) have been cultivated by Paraná state nurseries, which are the main producers of seedlings for restoration of this ecosystem (Martins et al., 2004). It is common practice to produce seedlings of species that are easy to collect, fast-growing or technically simple to grow, rather than many native species for which there is a lack of information on seed collection and germination protocols. Only $28 \%$ of the threatened species of the Araucaria Forest have been grown by state nurseries (Martins et al., 2004). In cases 


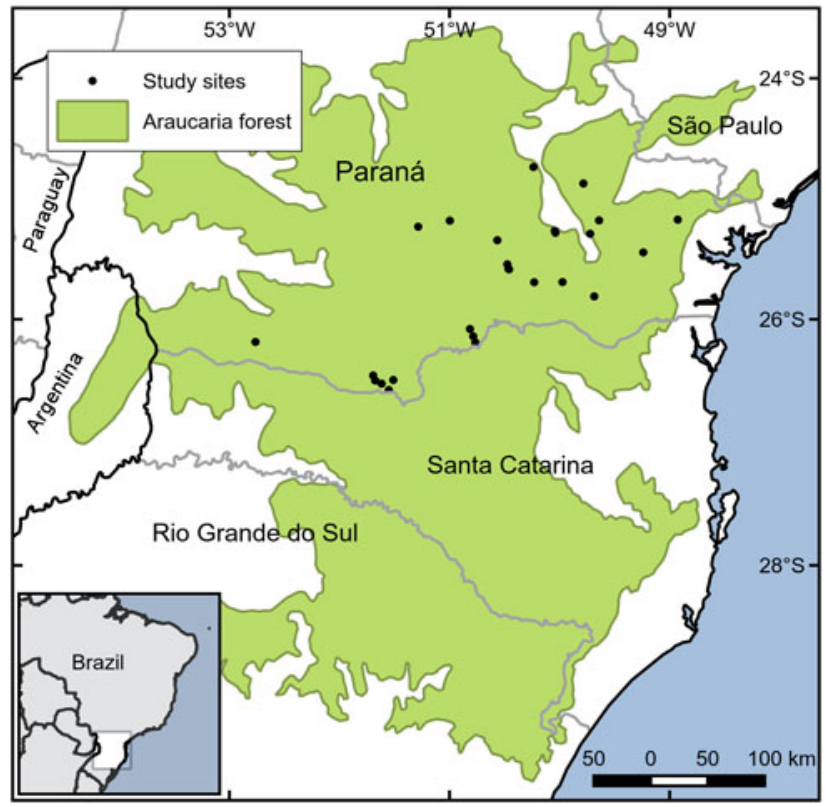

Fig. 1 Original distribution of Araucaria Forest in Paraná, Brazil (adapted from Olson et al., 2001). The rectangle on the inset indicates the location of the main map in Brazil.

where nurseries produce seedlings of threatened species, seeds are usually collected from a small number of trees, resulting in low genetic variability and fitness of seedlings (Zahawi \& Holl, 2014).

Fast-growing species play an important role in the restoration process. By developing a canopy layer and encouraging the return of seed dispersers and pollinators they can accelerate forest succession and the natural recruitment of a wide range of species (Elliott et al., 2013). However, in degraded and fragmented landscapes, such as the Araucaria Forest, restoration with a low diversity of species is unlikely to create the conditions necessary for dispersal of a wider range of naturally occurring species (Rodrigues et al., 2009). There is therefore a growing need for government agencies and conservation institutions to broaden the focus of seed collection and restoration efforts to include threatened or locally rare species as well as fast-growing species. Here we present a list of target species for conservation and restoration, identify sources of seeds (mother trees), estimate their frequency and abundance, and present basic information about phenological patterns of threatened and rare species in the Araucaria Forest.

\section{Study area}

The Araucaria Forest once covered the plateau regions in the centre and south of Paraná, at 800-1,200 m altitude (Fig. 1). The climate is humid subtropical, with cool summers and no dry season; frost is common in winter (Peel et al., 2007). Mean annual temperature is $18-22^{\circ} \mathrm{C}$ and annual precipitation is $1,100-2,000 \mathrm{~mm}$ (IAPAR, 1994). This subtropical forest is characterized by a dense physiognomy, marked by the dominance of emergent Araucaria angustifolia trees, with a mean height of $25-30 \mathrm{~m}$ (Scheer \& Blum, 2011).

\section{Methods}

A list of target species for seed collection was identified, including all threatened or rare tree species. Threatened species were defined as those listed in the regional, national or global Red Lists (SEMA, 1995; MMA, 2008; IUCN, 2013), including species categorized as Near Threatened. The threat categories of the various Red Lists were standardized according to IUCN (2013). Rare species were defined as those not included in official Red Lists but with few herbarium records (INCT, 2012) and a low frequency of occurrence, identified through surveys of the structure of the Araucaria Forest (Durigan, 1999; Pasdiora, 2003; Barddal et al., 2004; Geraldi et al., 2005; Seger et al., 2005; Watzlawick et al., 2005; Kozera et al., 2006; Cordeiro \& Rodrigues, 2007; Cordeiro, 2010).

A list of potential forest remnants was developed based on the occurrence of at least one target species. Data on the conservation status of these remnants were compiled based on our knowledge and on a technical report of the status of the Araucaria Forest (Castella \& Britez, 2004).

The final selection was based on geographical variability (including various floristic associations within the Araucaria Forest, to maximize genetic variability for each species), forest condition (fragments of medium to advanced successional stage, with a minimum size of 100 ha), and guarantee of protection (remnants located in protected areas or under other forms of conservation management, thus maximizing the likelihood of selected mother trees surviving and being available for long-term monitoring and seed collection).

Each selected forest remnant was surveyed intensively by walking along all existing trails to search for mother trees of target species. Species were initially identified in the field and later confirmed by comparison with herbarium specimens. The criteria for selection of mother trees were good health (free of damage, disease and infestation by insects) and full reproductive maturity (tree size, presence of old fruits, seeds or seedlings under the tree).

We attempted to map the highest number of mother trees in the maximum possible number of remnants. To obtain seeds with broad genetic variation, they were collected, when possible, from at least three populations of each species (Nogueira \& Medeiros, 2007), and from at least 12 trees per population (Vencovsky, 1987). When this was not possible, surveys aimed to identify at least 20 trees per species in the whole study area. Closely related individuals of the same 
species $(<50 \mathrm{~m}$ apart) were not selected, following Silva \& Higa (2006), and, where possible, selected mother trees were $>100 \mathrm{~m}$ apart. Shorter distances between selected individuals were accepted for rare species found only in a single cluster. For each mother tree selected the following data were recorded: reference number, species, remnant, geographical coordinates, diameter at breast height, trunk and total height, crown diameter, trunk shape, phenological phase, and distance and azimuth from a reference parameter (e.g. road, trail, fence, forest edge).

General reproductive phenological patterns were identified for the target species, following a review of literature and herbarium collection records (INCT, 2012). Preliminary information was verified during 52 field trips throughout the study area, covering all seasons, each year during March 2011March 2014. During each phenological evaluation mother trees were categorized according to the presence or absence of fruits and flowers, and the maturation phase. These data were used to develop a seed collection calendar.

\section{Results}

Target species The preliminary list of threatened and rare tree species included 71 taxa (Supplementary Table S1), of which 39 were threatened and 32 rare. Of the threatened species, 14 were listed only in the Paraná state Red List (SEMA, 1995), one was listed only in the national Red List (MMA 2008) and 17 were categorized as globally threatened (IUCN, 2013). Five species (A. angustifolia, Ocotea catharinensis, Ocotea odorifera, Ocotea porosa and Trithrinax brasiliensis) were included in all three Red Lists. Of the 32 rare species, analysis of secondary data revealed that some taxa had $<30$ records in herbarium collections and were generally not recorded in phytosociological studies. These include Colletia paradoxa, Maytenus boaria, Maytenus dasyclada, Agonandra excelsa, Castella tweedii, Picrasma crenata, Drimys angustifolia, Ouratea sellowii and Agarista pulchella.

Identification of seed sources in the field Twenty-six Araucaria Forest remnants (Fig. 1) in 14 municipalities were identified as priorities for seed collection. Ten of these are within officially protected areas. A total of $68.7 \mathrm{~km}$ of trails were surveyed (c. $2.6 \mathrm{~km}$ per remnant). Mother trees of 38 of the 71 target species were mapped (Supplementary Table $\mathrm{S} 1$ ). No individuals of the other 33 target species were found in the remnants studied. In total 1,027 individuals were marked as potential seed sources. The aim of selecting a minimum of 12 trees of each species in at least three remnants was achieved only for A. angustifolia, Cedrela fissilis, Ilex paraguariensis, $O$. porosa and Podocarpus lambertii, all of which except $P$. lambertii were observed in $>60 \%$ of the surveyed remnants, with an abundance of $>_{1}$ individual per $\mathrm{km}$. In contrast, $<_{2} \mathrm{O}$ individuals were found for 23 of the target species (all with $<0.3$ individuals per $\mathrm{km}$ ). Particularly rare species include $A$. excelsa, O. sellowii, Scutia buxifolia, Bunchosia pallescens, Maytenus aquifolia, Inga lentiscifolia and Quillaja brasiliensis, which were observed in $<8 \%$ of the forest remnants, with $<0.04$ individuals per $\mathrm{km}$.

Preliminary phenological assessment Phenological monitoring revealed that some species exhibited fruiting or flowering seasons that differed from those reported in the literature and herbarium data. The observed fruiting periods for O. odorifera and O. porosa differed by a few months to those reported, and larger variations between literature and field observations were observed for Oreopanax fulvus, O. sellowii, Cassia leptophylla, Casearia lasiophylla and Lafoensia pacari (Supplementary Table $\mathrm{S}_{1}$ ). For some species, including Tetrorchidium rubrivenium, Ocotea nutans and Zanthoxylum kleinii, we recorded a complete absence of reproductive structures throughout the phenological monitoring period.

\section{Discussion}

Definition of target species and identification of seed sources

The results indicate that the official list of threatened species for Paraná (SEMA, 1995) needs to be updated, as it does not include several rare species that are threatened by habitat loss and forest fragmentation. Possible candidates include Butia eriospatha, Cedrela lilloi, Chionanthus filiformis, Albizia edwallii, Albizia burkartiana, Agarista pulchella, Acca sellowiana, Ouratea sellowii, Agonandra excelsa, Castella tweedii, Picrasma crenata and Colletia paradoxa.

Several tree species were scarce in the study area (Supplementary Table $\mathrm{S}_{1}$ ), which is a common problem in seed collection and restoration of rare and threatened species (Jalonen et al., 2014). Low levels of forest cover, edge effects, fragmentation, and the presence of invasive species are all likely to drive changes in species composition, with rare and threatened species particularly affected (Phartyal et al., 2002). As demonstrated elsewhere in the Atlantic Rainforest, the general absence of fauna from degraded areas limits seed dispersal and pollination, further biasing species composition in favour of naturally dominant species (Silva \& Tabarelli, 2000).

The results also demonstrate the difficulty of obtaining a broad range of genotypes among seeds collected in the field. Despite considerable effort, we achieved our aim of locating a minimum of 12 trees from at least three populations for only five of the species studied. Way (2003) recommended sampling 50 individuals in a population as a benchmark figure to support the production of seedlings for restoration, but 
our results demonstrate the technical and logistical constraints of achieving this for extremely rare species. The number of target species of which no individuals were found in the Araucaria Forest indicates the need for research on the distribution, ecology and conservation of these threatened species.

Ex situ conservation, through seed collection and storage, is an important conservation strategy, but the existence of species with recalcitrant seeds (e.g. P. lambertii and A. angustifolia; Royal Botanic Gardens Kew, 2014) demonstrates the importance of ensuring the protection of mother trees in forest remnants. Given the difficulties in storing seeds of recalcitrant species in ex situ seed banks (Phartyal et al., 2002), the trees mapped are natural seed banks for restoration. Using and improving information on the distribution of mother trees is esssential for future restoration projects in Paraná.

\section{Preliminary phenological assessment}

Limited information and research on the phenology of seed development in wild species is a major constraint for restoration initiatives (Broadhurst et al., 2008). Furthermore, phenology and seed production vary significantly between individual trees of certain species, depending on climatic variation from year to year, and genetic and environmental variation (Way, 2003).

In the Araucaria Forest some species exhibited unexpected phenological patterns (and there are several species for which little is known of their reproductive biology). Tetrorchidium rubrivenium, for example, occurs in the Araucaria Forest but is more common in forests with warmer climates (INCT, 2012), which explains the difficulty in observing flowering or fruiting in this colder climate. The low fruit production observed for O. nutans and Z. kleinii (both endemic to the Araucaria Forest) may be explained by the fact that they are dioecious (Melo \& Zickel, 2004; Brotto et al., 2013); the individuals selected might have been male and therefore unable to produce fruits.

Ocotea odorifera is expected to fruit in alternate years (Inoue et al., 1984), and premature falling of fruits and the long period of maturation (Lorenzi, 1992) make it difficult to collect seeds from this species.

Understanding these details is necessary to ensure collection trips are timed appropriately to avoid wasted effort. Timing of seed collection is particularly difficult for species that exhibit seasonal fluctuations in phenology and for those with low levels of fruit production or that produce a high proportion of non-viable seeds, either as a result of predation or difficulties in maturation. According to Way (2003) the frequency of empty and damaged seeds varies among species, populations and seasons. This emphasizes the need for improved information on the reproductive biology of threatened species in the Araucaria Forest as a precursor to improved seed collection for restoration efforts.

\section{Future research and conservation}

We have identified sources of mother trees for 38 rare or threatened species and recorded information on their phenology, providing a basis for further seed collection efforts. However, there remain gaps in the information needed to support seed collection and seedling production of rare and threatened tree species for restoration. Firstly, there is a need for extensive surveys to identify mother trees among the 33 rare or threatened tree species not recorded in our surveys. Secondly, there is a need for further research on seed collection and seedling production protocols for the species we recorded, and to share these with the nurseries and restoration projects currently operating within the Araucaria Forest landscape.

There are good reasons for nurseries and restoration projects to adopt these protocols and incorporate rare and threatened species into their operations. Restoration of permanent forest in other areas of Brazilian Atlantic Rainforest has been proven to be more efficient when using a high diversity of tree species ( $>_{50}$; Barbosa et al., 2003), and the cost per seedling produced does not vary significantly among species (Rodrigues et al., 2011). If restoration practitioners could gain access to better information and reproductive material from a wide range of species they would be more likely to adopt these species in planting projects on a larger scale (Jalonen et al., 2014).

In addition to enhancing the restoration of rare and threatened species in the Araucaria Forest there is a growing need to ensure the immediate protection of mother trees before they disappear from the remaining forest fragments. Mother trees are essential for the survival of these species within the Araucaria Forest in the short term and are the major source of seed and genetic diversity for long-term recovery of the forest.

Future research and conservation need to focus on the factors that affect seed storage and the germination of individual seedlings. At a global level these issues are already being addressed by ex situ conservation projects such as the Millennium Seed Bank Partnership at Royal Botanic Gardens, Kew, UK. For many of the species found in the Araucaria Forest, however, their seed behaviour has yet to be studied extensively. For species threatened with extinction, effective seed storage may be an essential ex situ conservation measure.

Despite the many challenges associated with collection of seeds from rare and threatened species, our data represent a significant first step towards improving the genetic diversity and species richness of the seedlings produced in the Araucaria Forest. The methods described here may be of relevance to ecological restoration programmes elsewhere where the challenges of including rare and threatened tree species in seed collections, seedling production and planting operations are likely to be similar. 


\section{Acknowledgements}

We thank Jeniffer Grabias, Marcelo Bosco Pinto, Natalia Alejandra Bedrij, Tatiane Andressa Silva and Elivelton Gurski for assistance during the study. We also thank the Instituto Ambiental do Paraná and Instituto Chico Mendes de Conservação de Biodiversidade for their support, and the Fundação Grupo Boticário de Proteção à Natureza and the Global Trees Campaign for financial support.

\section{References}

Barbosa, L.M., Barbosa, J.M., Barbosa, K.C., Ротomati, A., Martins, S.E., Asperti, L.M. et al. (2003) Recuperação florestal com espécies nativas no Estado de São Paulo: pesquisas apontam mudanças necessárias. Florestar Estatístico, 6, 28-34.

Barddal, M.L., Roderjan, C.V., Galvão, F. \& Curcio, G.R. (2004) Caracterização florística e fitossociológica de um trecho sazonalmente inundável de floresta aluvial, em Araucária, PR. Ciência Florestal, 14, 37-50.

Broadhurst, L.M., Lowe, A., Coates, D.J., Cunningham, S.A., McDonald, M., Vesk, P.A. \& Yates, C. (2008) Seed supply for broadscale restoration: maximizing evolutionary potential. Evolutionary Applications, 1, 587-597.

Brotto, M.L., Cervi, A.C., Santos, E.P. (2013) O gênero Ocotea (Lauraceae) no estado do Paraná, Brasil. Rodriguésia, 64, 495-525.

Castella, P.R. \& Britez, R.M. (2004) A floresta com Araucária no estado do Paraná. Ministério do Meio Ambiente, Fundação de Pesquisas Florestais do Paraná, Brasília, Brazil.

CBD (Convention on Biological Diversity) (2010) Global Strategy for Plant Conservation 2011-2020. Http://www.cbd.int/gspc/ strategy.shtml [accessed 30 October 2014].

Cordeiro, J. (2010) Compartimentação pedológico-ambiental e sua influência sobre a florística e estrutura de um remanescente de Floresta Ombrófila Mista na região centro-sul do Paraná. $\mathrm{PhD}$ thesis. Universidade Federal do Paraná, Curitiba, Brazil.

Cordeiro, J. \& Rodrigues, W.A. (2007) Caracterização fitossociológica de um remanescente de Floresta Ombrófila mista em Guarapuava, PR. Revista Árvore, 31, 545-554.

Durigan, M.E. (1999) Florística, dinâmica e análise protéica de uma Floresta Ombrófila Mista em São João do Triunfo-PR. MSc thesis. Universidade Federal do Paraná, Curitiba, Brazil.

Elliott, S., Blakesley, D. \& Hardwick, K. (2013) Restoring Tropical Forests: A Practical Guide. Royal Botanic Gardens, Kew, UK.

Geraldi, S.E., Koehler, A.B. \& Kauano, E.E. (2005) Levantamento fitossociológico de dois fragmentos da Floresta Ombrófila Mista, em Tijucas do Sul, PR. Revista Acadêmica, 3, 27-36.

iAPAR (Instituto Agronômico do Paraná) (1994) Cartas climáticas do Estado do Paraná. IAPAR, Londrina, Brazil.

inCT (Instituto Nacional de Ciêcia e Tecnologia) (2012) Herbário Virtual da Flora e dos Fungos. Http://inct.splink.org.br/ [accessed 12 November 2012].

Inoue, M.T., Roderjan, C.V. \& Kuniyoshi, Y.S. (1984) Projeto Madeira do Paraná. FUPEF, Curitiba, Brazil.

IUCN (2013) IUCN Red List of Threatened Species. Http://www. iucnredlist.org [accessed 24 November 2013].

Jalonen, R., Thomas, E., Cavers, S., Bozzano, M., Boshier, D., BordÁCs, S. et al. (2014) Analysis of genetic considerations in restoration methods. In Genetic Considerations in Ecosystem Restoration Using Native Tree Species. State of the World's Forest
Genetic Resources-Thematic Study (eds M. Bozzano, R. Jalonen, E. Thomas, D. Boshier, L. Gallo, S. Cavers et al.), pp. 97-104. FAO and Bioversity International, Rome, Italy.

Kozera, C., Dittrich, V.A.O. \& Silva, S.M. (2006) Fitossociologia do componente arbóreo de um fragmento de Floresta Ombrófila Mista Montana, Curitiba, PR, BR. Floresta, 36, 225-237.

Leite, P. \& Klein, R.M. (1990) Vegetação. In Geografia do Brasil: região Sul. v. 2, pp. 113-150. Instituto Brasileiro de Geografia e Estatística, Rio de Janeiro, Brazil.

Liebsch, D., Marques, M.C.M. \& GoldenberG, R. (2008) How long does the Atlantic Rain Forest take to recover after a disturbance? Changes in species composition and ecological features during secondary succession. Biological Conservation, 141, 1717-1725.

Lorenzi, H. (1992) Árvores brasileiras: Manual de Identificação e Cultivo de Plantas Arbóreas Nativas do Brasil, Volume 1. Ed. Plantarum, Nova Odessa, Brazil.

Lorenzi, H. (1998) Árvores brasileiras: Manual de Identificação e Cultivo de Plantas Arbóreas Nativas do Brasil, Volume 2. Ed. Plantarum, Nova Odessa, Brazil.

Lorenzi, H. (2009) Árvores brasileiras: Manual de Identificação e Cultivo de Plantas Arbóreas Nativas do Brasil, Volume 3. Ed. Plantarum, Nova Odessa, Brazil.

MaAck, R. (2012) Geografia Física do Estado do Paraná, 4th edition. Editora UEPG, Ponta Grossa, Brazil.

Martins, S.S., Silva, I.C., Bortolo, L. \& Nepomuceno, A.N. (2004) Produção de mudas de espécies florestais nos viveiros do Instituto Ambiental do Paraná. Clichetec, Maringá, Brazil.

Melo, M.F.F. \& ZicKel, C.S. (2004) Os gêneros Zanthoxylum L. e Esenbeckia Kunth (Rutaceae) no Estado de Pernambuco, Brasil. Acta Botanica Brasilica, 18, 73-90.

Merritt, D.J. \& Dixon, K.W. (2014) Seed availability for restoration. In Genetic Considerations in Ecosystem Restoration Using Native Tree Species. State of the World's Forest Genetic ResourcesThematic Study (eds M. Bozzano, R. Jalonen, E. Thomas, D. Boshier, L. Gallo, S. Cavers et al.), pp. 97-104. FAO and Bioversity International, Rome, Italy.

Mittermeier, R.A., Myers, N. \& Mittermeier, C.G. (1999) Hotspots: Earth's Biologically Richest and Most Endangered Terrestrial Ecoregions. CEMEX, Mexico City, Mexico.

Mma (Ministro do Meio Ambiente) (2008) Lista Oficial das Espécies da Flora Brasileira Ameaçadas de Extinção. Instrução Normativa No. 6, 2008. Http://www.mma.gov.br/estruturas/ascom_ boletins/_arquivos/83_19092008034949.pdf [accessed 28 August 2014].

Myers, N., Mittermeier, R.A., Mittermeier, C.G., Da Fonseca, G.A.B. \& Kent, J. (2000) Biodiversity hotspots for conservation priorities. Nature, $403,853-858$.

Nogueira, A.C. \& Medeiros, A.C.S. (2007) Coleta de Sementes florestais nativas. Circular Técnica 144. Embrapa Florestas, Brasília, Brazil.

Olson, D.M., Dinerstein, E., Wikramanayake, E.D., Burgess, N.D., Powell, G.V.N., Underwood, E.C. et al. (2001) Terrestrial ecoregions of the world: a new map of life on Earth. BioScience, 51, 933-938.

Pasdiora, A.L. (2003) Florística e fitossociologia de um trecho de floresta ripária em dois compartimentos ambientais do rio Iguaçu, Paraná, Brasil. MSc thesis. Universidade Federal do Paraná, Curitiba, Brazil.

Peel, M.C., Finlayson, B.L. \& McMahon, T.A. (2007) Updated world map of the Köppen-Geiger climate classification, Hydrology and Earth System Sciences, 11, 1633-1644.

Phartyal, S.S., Thapliyal, R.C., Koedam, N. \& Godefroid, S. (2002) Ex situ conservation of rare and valuable forest tree species through seed-gene bank. Current Science, 83, 1351-1357. 
Ribeiro, M.C., Metzger, J.P., Martensen, A.C., Ponzoni, F.J. \& Hirota, M.M. (2009) The Brazilian Atlantic Forest: how much is left, and how is the remaining forest distributed? Implications for conservation. Biological Conservation, 142, 1141-1153.

Rodrigues, R.R., Gandolfi, S., Nave, A.G., Aronson, J., Barreto, T.E., Vidal, C.Y. \& Brancalion, P.H.S. (2011) Large-scale ecological restoration of high-diversity tropical forests in SE Brazil. Forest Ecology and Management, 261, 1605-1613.

Rodrigues, R.R., Lima, R.A.F., Gandolfi, S. \& Nave, A.G. (2009) On the restoration of high diversity forests: 30 years of experience in the Brazilian Atlantic Forest. Biological Conservation, 142, 1242-1251.

Rojas-Briales, E. \& Weise, S. (2014) Foreword. In Genetic Considerations in Ecosystem Restoration Using Native Tree Species. State of the World's Forest Genetic Resources-Thematic Study (eds M. Bozzano, R. Jalonen, E. Thomas, D. Boshier, L. Gallo, S. Cavers et al.), p. iii. FAO and Bioversity International, Rome, Italy.

Royal Botanic Gardens Kew (2014) Seed Information Database (SID) Version 7.1. Http://data.kew.org/sid/ [accessed 15 September 2014].

Scheer, M. \& Blum, C.T. (2011) Arboreal diversity of the Atlantic Forest of Southern Brazil: from the beach ridges to the Paraná river. In The Dynamical Processes of Biodiversity: Case Studies of Evolution and Spatial Distribution (eds O. Grillo \& G. Venora), pp. 109-134. INTECH, Rijeka, Croatia.

Seger, C.D., Dlugosz, F.L., Kurasz, G., Martinez, D.T., Ronconi, E., DE MELo, L.A.N. et al. (2005) Levantamento florístico e análise fitossociológica de um remanescente de floresta ombrófila mista localizado no município de Pinhais, Paraná-Brasil. Revista Floresta, 35, 291-302.

SEMA (1995) Lista vermelha de plantas ameaçadas de extinção no estado do Paraná. SEMA/GTZ, Curitiba, Brazil.

Silva, J.M.C. \& Tabarelli, M. (2000) Tree species impoverishment and the future flora of the Atlantic forest of northeast Brazil. Nature, 404, 72-74.

Silva, L.D. \& Higa, A.R. (2006) Planejamento e implantação de pomares de sementes de espécies florestais nativas. In Pomar de sementes de espécies florestais nativas (eds A.R. Higa \& L.D. Silva), pp. 13-39. FUPEF, SM-PPGE, Curitiba, Brazil.

Vencovsky, R. (1987) Tamanho efetivo populacional na coleta e preservação de germoplasmas de espécies alógamas. IPEF, 35, 79-84. Watzlawick, L.F., Sanqueta, C.R., Valério, A.F. \& Silvestre, R. (2005) Caracterização da composição florística e estrutura de uma Floresta Ombrófila Mista, no município de General Carneiro (PR). Ambiência, 1, 229-237.

WAY, M.J. (2003) Collecting seed from non-domesticated plants for long-term conservation. In Seed Conservation: Turning Science Into Practice (eds R.D. Smith, J.B. Dickie, S.H. Linington, H.W. Pritchard \& R.J. Probert), pp. 163-201. The Royal Botanic Gardens, Kew, London, UK.

ZaHAWI, R.A. \& HolL, K.D. (2014) Evaluation of different tree propagation methods in ecological restoration in the neotropics. In Genetic Considerations in Ecosystem Restoration Using Native Tree Species. State of the World's Forest Genetic Resources-Thematic Study (eds M. Bozzano, R. Jalonen, E. Thomas, D. Boshier, L. Gallo, S. Cavers et al.), pp. 85-96. FAO and Bioversity International, Rome, Italy.

\section{Biographical sketches}

PABLO HOFFMANN is a conservationist working on the propagation of rare and threatened species of the Araucaria Forest, and monitoring their development. Christopher Blum's research interests include increasing the knowledge and understanding of the autoecology and conservation status of rare and threatened species in southern Brazil. Santiago Velazco's research interests lie in plant ecology, with a focus on the biogeography of northern Argentina and central and southern Brazil. DAvid Gill supports the development of conservation projects for threatened tree species as part of the Global Trees Campaign. MARILIA BORGO is a conservationist who specializes in quantifying biodiversity and developing strategies for payment for environmental services. 